\title{
Identifikasi Pengaruh Perkembangan Tanaman Terhadap Dua Jenis Ikan Menggunakan Sistem Akuaponik
}

\author{
Faldi Saliko ${ }^{1)}$, Evi Sunarti Antu' ${ }^{2)}$, Romi Djafar ${ }^{3)}$ \\ 1,2,3) Program Studi Mesin dan Peralatan Pertanian, Politeknik Gorontalo \\ Jl. Muchlis Rahim, Desa Ponggulo Barat, Kec. Botupingge, Kab. Bone Bolango, Gorontalo, Indonesia \\ e-mail: faldisaliko07@gmail.com
}

\begin{abstract}
ABSTRAK
Akuaponik merupakan kombinasi sistem akuakultur dan hidroponik yang saling menguntungkan. Akuakultur merupakan budidaya ikan, sedangkan hidroponik dapat diartikan memberdayakan air. Dalam proses akuaponik tanaman memanfaatkanunsur hara yang berasal dari kotoran ikan. bakteri pengurai akan mengubah kotoran ikan menjadi unsur nitrogen, kemudian unsur tersebut akan dimanfaatkan sebagai sumber nutrisi bagi tanaman. Tujuan dari penelitian ini adalah untuk mengetahui perbandingan sistem akuaponik ikan Lele dan ikan terhadap pertumbuhan tanaman kangkung dan sawi. Peneletian kali ini dilakukan di kecamatan Tilongkabila Kabupaten Bone Bolango Provinsi Gorontalo. Metode yang digunakan pada penelitian ini adalah metode identifikasi. Terdapat dua kolam ikan yang berbeda yaitu kolam ikan Lele dan kolam ikan Mas. Teknik pengumpulan data dilakukan dengan cara identifikasi, pengamatan dan dokumentasi. Data yang diperoleh dianalisis deskriptif kuantitatif. Berdasarkan hasil penelitian menunjukan bahwa pertumbuhan tinggi tanaman, lebar daun, panjang daun kangkung pada kolam ikan Mas lebih unggul dari pada kolam ikan Lele sedngkan untuk banyak daun kangkung lebih baik kolam ikan Lele dari pada ikan Mas. Data penelitian untuk tinggi tanaman, lebar daun, banyak daun, dan panjang daun untuk tanaman sawi lebih unggul kolam ikan Mas dari pada kolam ikan Lele.
\end{abstract}

Kata Kunci: akuaponik, ikan, tanaman

\begin{abstract}
Aquaponics is a mutually beneficial combination of aquaculture and hydroponic systems. Aquaculture is the cultivation of fish, while hydroponics means empowering water. In the aquaponics process, plants utilize nutrients derived from fish waste. Decomposing bacteria will convert fish waste into nitrogen, then these elements will be used as a source of nutrition for plants. The purpose of this study was to determine the comparison of the aquaponics system of catfish and fish on the growth of kale and mustard greens. This research was conducted in Tilongkabila sub-district, Bonebolango Regency, Gorontalo Province. The method used in this research is the method of identification. There are two different fish ponds, namely the catfish pond and the goldfish pond. The data collection technique is done by identifying, observing and documenting. The data obtained were analyzed descriptively quantitatively. The results showed that the growth of plant height, leaf width, leaf length of kale in goldfish ponds was superior to catfish ponds. Whereas for many kale leaves, catfish ponds were better than goldfish. Research data plant height, leaf width, leaf number, and leaf length for mustard greens were superior to goldfish ponds than catfish ponds.
\end{abstract}

Keywords: aquaponics, fish, vegetables 


\section{PENDAHULUAN}

Di zaman yang serba modern ini, masyarakat Indonesia khususnya daerah Gorontalo mulai merasakan banyak sekali dampak dari mengonsumsi makanan, baik negatif maupun positif. Beberapa diantaranya lebih mengeluhkan dampak buruk makanan bagi kesehatan, baik itu makanan cepat saji, buah-buahan maupuan sayur-sayuran. Hal ini merupakan efek dari banyaknya penggunaan bahanbahan kimia, terutama dalam proses budidaya tanaman dan sayuran seperti penggunaan pupuk dan pestisida. Untuk kebutuhan peningkatan hasil panen terkadang para petani tidak menghiraukan akan dampak yang akan terjadi karena penggunaan bahan-bahan kimia tersebut. Telah banyak teknologi-teknologi dan metode yang digunakan sebagai alternatif dalam menanggulangi masalah tersebut. Salah satunya adalah penggunaan metode akuaponik sebagai media budidaya tanaman dan ikan.

Akuaponik adalah perkawinan antara budidaya ikan (akuakultur) dan tanaman (hidroponik) secara bersama-sama dalam suatu ekosistem yang saling menguntungkan satu sama lain dengan menggunakan bantuan bakteri alami untuk mengubah limbah dan sisa pakan ikan menjadi pupuk organik sebagai nutrisi tanaman dengan kata lain, akuaponik adalah sistem di mana tanaman dan ikan tumbuh bersama. Penggabungan kedua sistem (akuakultur dan hidroponik) memiliki keunggulan bahwa terjadi proses daur ulang sehingga limbah dari sistem budidaya ikan menjadi input untuk sistem hidroponik. Dengan menggabungkan akuakultur menjadi akuaponik, limbah yang dibuang ke alam menjadi minimal. Sehingga dapat dikatakan bahwa sistem akuaponik merupakan sistem yang ramah lingkungan (Dinas Pangan, Pertanian dan Perikanan Kota Pontianak).

Budidaya ikan sistem akuaponik di Indonesia merupakan teknologi relatif baru dan belum banyak diketahui oleh kalangan pembudidaya ikan. Teknologi budidaya ikan sistem akuaponik adalah gabungan dari budidaya ikan (akuakultur) dan budidaya tanaman sayuran dalam satu kesatuan sistem. (Dauhan et al, 2014 dan Diver, 2005). Diantara manfaat sistem akuaponik adalah menghasilkan dua produk sekaligus, yakni ikan dan sayuran yang memiliki nilai gizi dan protein yang baik, juga tanpa pengaruh bahan-bahan kimia sehingga lebih sehat. Disamping itu, sistem ini memiliki kemudahan dalam pemeliharaan dan berkelanjutan.
Berdasarkan penelitian sistem Akuaponik yang sebelumnya dibuat oleh Habiburrohman (2008) yang meneliti satu tanaman sayuran yaitu sayur sawi dan satu jenis yaitu ikan Lele saja maka pada penelitian ini dilakukan studi ekseprimen yang sama dengan menambahkan dua jenis tanaman sayuran yaitu sayur kangkung dan sawi dan dua jenis ikan yaitu ikan Lele dan Mas. Hal ini karenakan kedua jenis ikan ini memiliki nilai ekonomis yang cukup tinggi, dan mudah di budidayakan. Tujuan dari penelitian adalah merancang bangun sistem hidroponik dan mengetahui pertumbuhan tanaman sawi dan kangkung terhadap jeis ikan pada sistem akuaponik.

\section{METODE PENELITIAN}

\section{Metode dan Jenis Penelitian}

Metode penelitian ini menggunakan metode kuantitatif. Data-data dikumpukan melalui hasil penelitian dari masing-masing sampel yang menjadi objek penelitian. Pengamatan dilakukan setiap 3 hari selama dua bulan dikarenakan untuk memantau pertumbuhan dan perkembangan tanaman kangkung dan sawi. Pada pengamatan tersebut di lakukan pengukuran tinggi tanaman, lebar daun, jumlah daun, warna daun, panjang akar.

\section{Perancangan Sistem Akuaponik}

Sistem akuaponik yang digunakan dalam penelitian ini dapat dilihat pada Gambar 1. Sistem ini memiliki beberapa bagian seperti atap yang terbuat dari plastik ultra violet, tiang penyangga, kolam, dan rangkaian sistem akuaponik seperti sirkulasi aliran air.

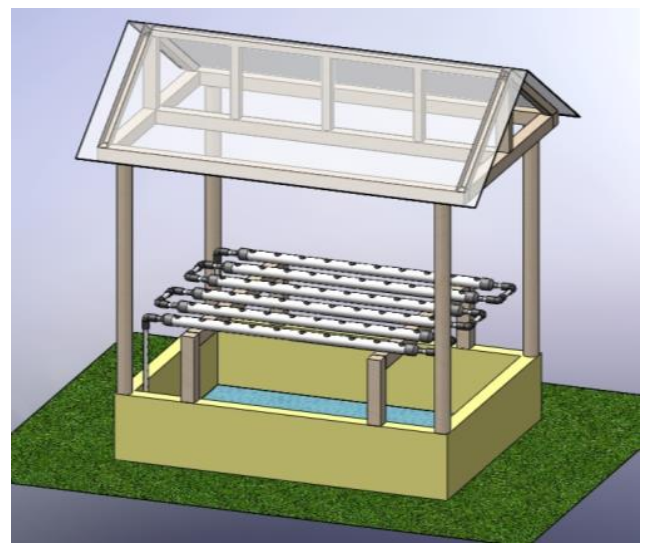

Gambar 1. Desain Sistem Akuaponik 


\section{Pengujian Sistem Akuaponik}

1. Instalasi sistem

- Membuat instalasi akuaponik dengan sistem NFT, kemudian membuat lubang pada talang dengan jarak $20 \mathrm{~cm}$ per lubang

- Memasang sambungan pipa untuk saluran input dan saluran output

- Memasang netpot pada talang.

- Menyambungkan selang input dari pompa air menuju talang.

- Mengisi kolam dengan air sebanyak 168 liter

- Memastikan tidak ada kebocoran pada rangkaian instalasi, kemudian menyalakan pompa air celup untuk disirkulasi.

2. Penyemaian dan penanaman

- Memotong rockwool dengan gergaji besi menjadi bentuk persegi.

- Potongan rockwool dimasukkan ke dalam tray semai dan melubangi rockwool dengan kedalaman sekitar $0,5 \mathrm{~cm}$.

- Mengisi tiap lubang tanam dengan satu benih sawi dan kangkung kemudian disimpan pada tempat yang tidak terpapar sinar matahari secara langsung.

- Setelah berumur 3 hari atau benih sudah menjadi kecambah, benih dipindahkan ke tempat yang terpapar sinar matahari.

- Benih siap pindah tanam setelah berumur satu minggu.

- Memindahkan rockwool yang berisi benih ke dalam netpot dan memasukkannya ke dalam instalasi akuaponik (talang).

3. Pengamatan dan pengukuran

Pengamatan dilakukan setiap 3 hari selama dua bulan dikarenakan untuk memantau pertumbuhan dan perkembangan tanaman kangkung dan sawi. Pada pengamatan tersebut di lakukan pengukuran tinggi tanaman, lebar daun, jumlah daun, warna daun, panjang akar.

\section{HASIL DAN PEMBAHASAN}

\section{Pengukuran Parameter Sistem Akuaponik}

Parameter yang dimaksudkan adalah parameter-parameter yang diperlukan dalam sistem akuaponik selama proses pertumbuhan, baik ikan maupun sayuran. Parameter ini meliputi suhu dan pH. Pemilihan ini didasarkan pada kenyataan bahwa pertumbuhan tanaman dan hewan dipengaruhi oleh beberapa faktor, diantaranya suhu dan $\mathrm{pH}$.
1. Pengukuran suhu

Pengukuran suhu air dilakukan pada minggu pertama dan kedua dari dua jenis kolam ikan yang berbeda. Berdasarkan hasil penelitian yang dilakukan pada minggu pertama dan kedua mempunyai suhu rata-rata yang relatif sama, baik pada kolam ikan mas maupun ikan lele. Suhu kolam setelah dilakukan pengukuran pada mingu pertama dan kedua berkisar antara $28-29{ }^{\circ} \mathrm{C}$. Tidak adanya perbedaan suhu dikarenakan kedua kolam tersebut berdekatan dan mengambil sumber air yang sama.

2. Pengukuran $\mathrm{pH}$

Uji $\mathrm{pH}$ dilakukan dengan mengunakan $\mathrm{pH}$ indikator universal. Pengukuran $\mathrm{pH}$ dilakukan pada minggu pertama dan kedua. Nilai pH pada minggu pertama pada ikan Mas dengan rata-rata yaitu 7,35 dan minggu kedua 7,45 sedangkan nilai $\mathrm{pH}$ pada kolam ikan Lele pada minggu pertama dengan ratarata yaitu 6,80 dan minggu kedua 7,00. Nilai $\mathrm{pH}$ yang ideal untuk tanaman kangkung dan sawi yaitu 6-7.

\section{Pertumbuhan Tanaman Kangung}

Pengamatan pada tanaman kangkung pada penelitian ini meliputi tinggi tanaman, banyak daun, lebar daun, dan panjang daun yang dilakukan setiap 3 hari satu kali pada saat tanaman sudah dipindahkan pada sistem akuaponik. Hasil pengamatan tanaman kangkung pada minggu pertama dan minggu kedua akan disajikan pada Gambar 2 dan 3.

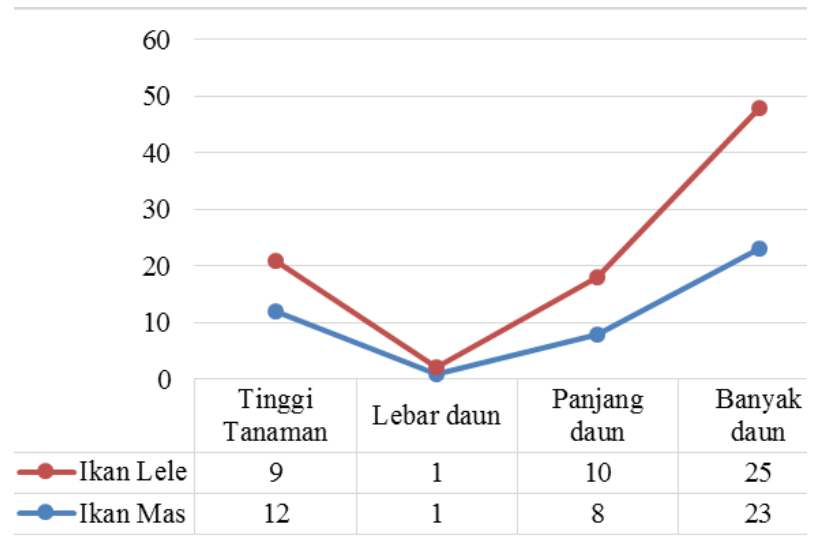

Gambar 2. Pertumbuhan Kangkung Minggu ke-1

Gambar 2 menunjukan bahwa pertumbuhan tanaman kangkung pada kedua jenis akuaponik yang berbeda terdapat perbedaan pada tinggi tanaman untuk akuaponik ikan Lele $9 \mathrm{~cm}$ sedangkan tinggi tanaman pada akuaponik ikan mas $12 \mathrm{~cm}$, lebar daun untuk kedua jenis akuaponik sama, panjang daun untuk akuaponik ikan Lele $8 \mathrm{~cm}$ sedangkan panjang 
daun pada akuaponik ikan Mas $10 \mathrm{~cm}$, banyak daun pada akuaponik ikan Lele sebanyak 25 helai daun sedangkan banyak daun pada akuaponik ikan Mas sebanyak 23 helai.

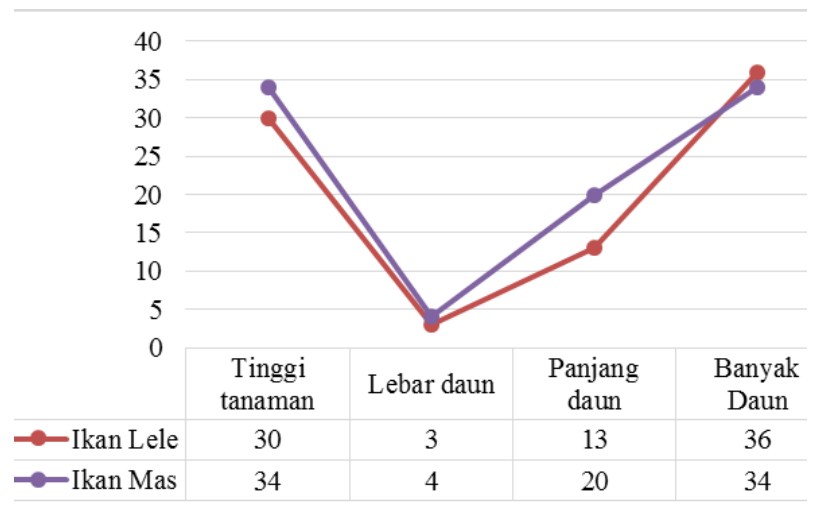

Gambar 3. Pertumbuhan Kangkung Minggu ke-2

Grafik pada Gambar 3 menunjukan bahwa pertumbuhan tanaman kangkung pada kedua jenis akuaponik yang berbeda terdapat perbedaan pada tinggi tanaman untuk akuaponik ikan Lele $30 \mathrm{~cm}$ sedangkan tinggi tanaman pada akuaponik ikan mas $34 \mathrm{~cm}$, lebar daun untuk akuaponik ikan lele $3 \mathrm{~cm}$ sedangkan lebar daun pada akuaponik ikan Mas 4 $\mathrm{cm}$, panjang daun untuk akuaponik ikan Lele $13 \mathrm{~cm}$ sedangkan panjang daun pada akuaponik ikan Mas $20 \mathrm{~cm}$, banyak daun pada akuaponik ikan Lele sebanyak 36 helai daun sedangkan banyak daun pada akuaponik ikan Mas sebanyak 34 helai.

\section{Pertumbuhan Tanaman Sawi}

Sebagaimana tanaman kangkung, pengamatan pada tanaman sawi meliputi tinggi tanaman, banyak daun, lebar daun, dan panjang daun dan dilakukan setiap 3 hari satu kali pada saat tanaman sudah dipindahkan pada sistem akuaponik. Hasil peneletian pada pada tanaman sawi akan disajikan pada Gambar 4 dan 5.

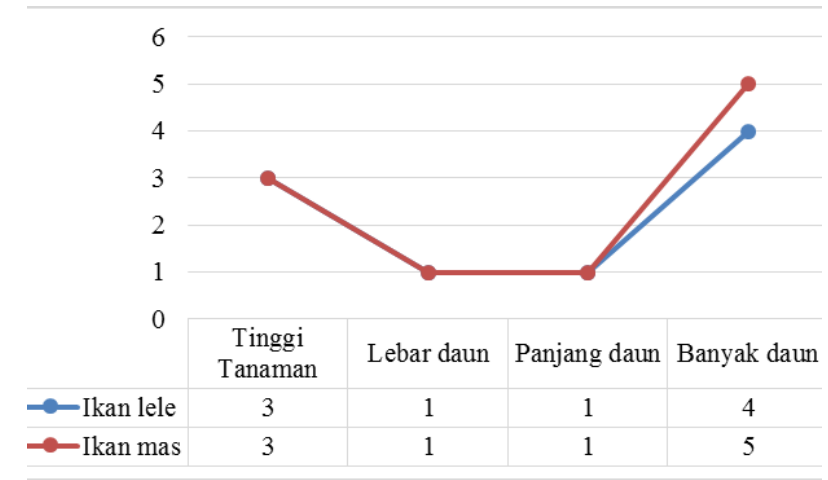

Gambar 4. Pertumbuhan Sawi Minggu ke-1

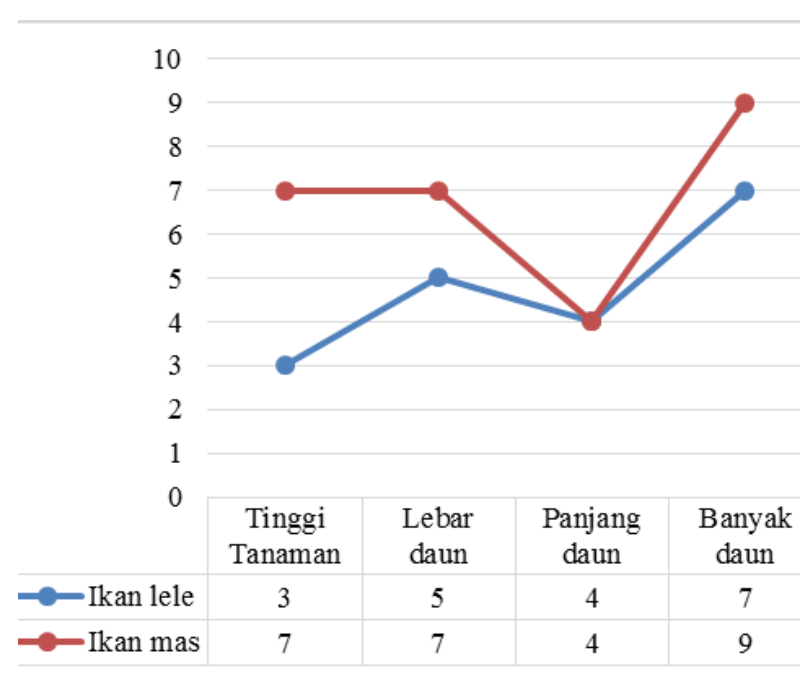

Gambar 5. Pertumbuhan Sawi Minggu ke-2

Grafik pada Gambar 4 menunjukan bahwa pertumbuhan tanaman sawi pada kedua jenis akuaponik yang berbeda mengalami persamaan mulai dari tinggi tanaman, lebar daun, dan panjang daun, sedangkan untuk banyak daun akuaponik ikan Lele hanya 4 helai daun dan untuk akuaponik ikan Mas 5 helai daun.

Berbeda pada minggu pertama yang banyak persamaan pada minggu kedua (Gambar 5) sudah terlihat jelas perbedaan pada pertumbuhan tanaman sawi mulai dari tinggi tanaman pada akuaponik ikan Lele $3 \mathrm{~cm}$ sedangkan pada akuaponik ikan Mas 7 $\mathrm{cm}$, Lebar daun pada akuaponik ikan Lele $5 \mathrm{~cm}$ sedangkan pada akuaponik ikan Mas $7 \mathrm{~cm}$, untuk panjang daun dari kedua jenis akuaponik sama, dan untuk banyak daun pada akuaponik ikan Lele 7 helai daun sedangkan pada akuapaonik ikan Mas 9 helai daun.

\section{KESIMPULAN}

Berdasarkan hasil penelitian dapat diambil beberapa kseimpulan sebagai berikut:

1. Sistem akuaponik dengan dimensi kolam tinggi $80 \mathrm{~cm}$, panjang $300 \mathrm{~cm}$, dan lebar $200 \mathrm{~cm}$.

2. Pertumbuhan tanaman kangkung pada media kolam ikan Mas memiliki tinggi tanaman $34 \mathrm{~cm}$, lebar daun $4 \mathrm{~cm}$, panjang daun $20 \mathrm{~cm}$, dan banyak daun 34 helai, sedangkan pada media ikan Lele memiliki tinggi tanaman $30 \mathrm{~cm}$, lebar daun $3 \mathrm{~cm}$, panjang daun $13 \mathrm{~cm}$, dan banyak daun 36 helai.

3. Pertumbuhan tanaman sawi pada media Ikan Mas memiliki tinggi $7 \mathrm{~cm}$, lebar daun $7 \mathrm{~cm}$, panjang daun $4 \mathrm{~cm}$, dan banyak daun 9 helai, 
sedangkan pada media ikan lele memiliki tinggi tanaman $3 \mathrm{~cm}$, lebar daun $5 \mathrm{~cm}$, panjang daun 4 $\mathrm{cm}$, dan banyak daun 7 helai.

\section{DAFTAR PUSTAKA}

Afiesh Sp "Ikan Lele" (On-line) tersedia di http://afiesh.blogspot.com/2013/02/ikan-

Lele-clarias-sp.html. Diakses pada 27 Desember 2020.

Eko Haryanto, et.al. Sawi dan selada, (Jakarta: Penebar Swadaya, 2007), h. 8-9.

Fernandes, "Budidaya Sawi Hijau" (On-line), tersedia di: http://andisubawa.worpress.com/2010/03/12/ budidaya-sawi-hijau/. Diakses pada 25 Desember 2020.

Galuh Budi Widiyantara, "Kinerja Produksi Pendederan Lele Sangkuriang (Clarias sp.) Melalui Penerapan Teknologi Pergantian Air $50 \%$, 100\%, Dan 150\% Per Hari”. (Skripsi Institut Pertanian Bogor, Bogor, 2009), h. 3.

Habiburrohman, Aplikasi teknologi Akuaponik sederhana pada budidaya ikan air tawar untuk optimalisasipertumbuhan tanaman sawi (Brassica juncea L), Bandar Lampung, 2018.

M. Ghufran H, Kordi K, Budidaya Ikan Lele di Kolam Terpal, (Yogyakarta: ANDI, 2010), h. 2-3.

Saparinto, C., \& Susiana, R., (2014), Panduan Lengkap Budidaya Ikan dan Sayuran dengan Sistem Akuaponik, Yogyakarta: Lily Publisher.

Saparinto, C., (2012), Panduan Lengkap Bisnis dan Budidaya Lele Unggul, Yogyakarta: Lily Publisher. 